\title{
Environmental and Ecological Effects of Climate Change on Venomous Marine and Amphibious Species in the Wilderness
}

\author{
Robert K. Needleman, MD; Isabelle P. Neylan; Timothy B. Erickson, MD, FACEP, FACMT, FAACT \\ From the Department of Emergency Medicine, Cook County Hospital, Chicago, IL (Dr Needleman); the Institute of Marine Sciences, University of \\ North Carolina Chapel Hill, Morehead City, NC (Ms Neylan); and the Department of Emergency Medicine, Division of Medical Toxicology, \\ Brigham and Women's Hospital, Harvard Medical School, Harvard Humanitarian Initiative, Boston, MA (Dr Erickson).
}

\begin{abstract}
Introduction-Recent analyses of data show a warming trend in global average air and sea surface ocean temperatures. The atmosphere and ocean have warmed, the amounts of snow and ice have diminished, the sea level has risen, and the concentrations of greenhouse gases have increased. This article will focus on climate change and projected effects on venomous marine and amphibious creatures with the potential impact on human health.

Methods-Retrospective analysis of environmental, ecological, and medical literature with a focus on climate change, toxinology, and future modeling specific to venomous aquatic and amphibious creatures. Species included venomous jellyfish, poisonous fish, crown-of-thorns starfish, sea snakes, and toxic frogs.

Results-In several projected scenarios, rising temperatures, weather extremes, and shifts in seasons will increase poisonous population numbers, particularly with certain marine creatures like jellyfish and crown-of-thorns starfish. Habitat expansions by lionfish and sea snakes are projected to occur. These phenomena, along with increases in human populations and coastal development will likely increase human-animal encounters. Other species, particularly amphibious toxic frogs, are declining rapidly due to their sensitivity to any temperature change or subtle alterations in the stability of their environment. If temperatures continue to rise to record levels over the next decades, it is predicted that the populations of these once plentiful and critically important animals to the aquatic ecosystem will decline and their geographic distributions will shrink.

Conclusion-Review of the literature investigating the effect and forecasts of climate change on venomous marine and amphibious creatures has demonstrated that temperature extremes and changes to climatic norms will likely have a dramatic effect on these toxicological organisms. The effects of climate change on these species through temperature alteration and rising coastal waters will influence each species differently and in turn potentially affect commercial industries, travel, tourism, and human health.
\end{abstract}

Keywords: jellyfish, lionfish, stingrays, crown-of-thorns starfish, sea snakes, amphibians, poison dart frogs, envenomation, toxinology

\section{Introduction}

Recent analyses of data show a clear warming trend in global average air and ocean temperatures. ${ }^{1}$ The past 4 years (2014-2017) have been the warmest on record since

Corresponding author: Dr. Robert K. Needleman, MD, Department of Emergency Medicine, Cook County Hospital, Chicago, IL 60612; e-mail: robert.k.needleman@ gmail.com.

Submitted for publication May 2017

Accepted for publication April 2018.
1880. Each of the last 3 decades has been successively warmer at the Earth's surface than any preceding decade since 1850. In the Northern Hemisphere, 1983 to 2012 was likely the warmest 30 -year period of the last 1400 years. The global average of combined land and ocean surface temperature data as calculated by a linear trend, show a warming of $0.9^{\circ} \mathrm{C}\left( \pm 0.2^{\circ} \mathrm{C}\right)$ over a period 1880 to 2012 , when multiple independently produced data points exist. ${ }^{2}$

The surface $300 \mathrm{~m}$ of the world's oceans has warmed by $9.3^{\circ} \mathrm{C}$ since the mid-1950s. ${ }^{3}$ Climate models project 
that global warming due to human influences will be 0.1 to $0.2^{\circ} \mathrm{C}$ per decade for the next 2 decades, and that sea surface temperatures (SSTs) will rise nearly everywhere. ${ }^{4,5}$

Due to such temperature increases, glaciers have diminished and the mean sea level has risen. Over the period 1901 to 2010, global mean sea level rose by 0.19 $\mathrm{m}$, which is higher than the mean rate estimated for the previous 2 millennia. ${ }^{2}$ Rising coastal waters, however, do not necessarily equate to more marine habitat. Certain environments, such as marshes, mangroves, and other biogenic shoreline habitats, will experience "habitat squeeze" due to rising sea levels and continued human development in these areas. This degradation and loss of habitat may decrease native venomous aquatic species. Conversely, these creatures may begin to appear in new areas where they were not previously described.

By the end of this century, it is predicted that over $50 \%$ of the world's population will be living within 100 $\mathrm{km}$ of a coastline. With increasing population and coastal development, more humans are venturing into aquatic environments for recreational activities, vacations, tropical destinations, and coastal living. ${ }^{6}$ As a result, the opportunity for humans to encounter venomous marine life that inhabit reefs and shallow marine waters increases. ${ }^{7}$ Additionally, the risk and the spectrum of marine envenomation are often unknown to nonindigenous travelers. As reported in 1 study, returning travelers in recent years were more likely to encounter coral-related injuries and experience marine envenomation from jellyfish and stonefish. This was followed in frequency by starfish, stingrays and lionfish. ${ }^{8}$

This article will uniquely focus on climate change and its affect upon toxinology (the scientific discipline dealing with microbial, plant, and animal venoms, poisons, and toxins) specific to venomous marine and amphibious creatures. To our knowledge, a review of this kind does not exist in the literature apart from species-specific investigations. The effects of climate change on these species will potentially affect commercial industries, travel, tourism, and human health. Our objectives are to describe i) how climate change affects the species' habitat, ii) how species are responding, and then iii) discuss the effects upon human health.

\section{Methods}

A search of Web of Science core database collection including MEDLINE, Biological Abstracts, and SciELO Citation index to include citations since 1970 with identified keywords was undertaken. Keywords included the following: climate change, anthropogenic climate change, climate, global warming, temperature change, environmental change, envenomation, venomous, distribution, jellyfish, box jellyfish, Portuguese man o' war, sea nettle, Irukandji venomous fish, stingrays, lionfish, scorpion fish, stonefish, crown-of-thorns, sea snakes, sea kraits, blue-ringed octopus, puffer fish, porcupine fish, poison dart frogs, and poison arrow frogs, (common and scientific names were used for species). Each keyword was used independently and, when appropriate, in combination with additional keyword(s) to identify relevant articles. The coauthors screened titles and abstracts of all articles identified by the search. Eligibility criteria included peer reviewed, published studies. In particular, we analyzed multiple "ecological niche model" studies that project future species distribution given a set of climatic predictor variables, which were relevant to the topic.

\section{Results}

\section{JELLYFISH}

Coelenterates (phylum Cnidaria) include sea anemones, corals, and jellyfish, whose stings are the most common marine envenomation. Although most species are typically found in temperate and tropical waters, ${ }^{7}$ jellyfish encounters also occur in colder marine regions such as Scandinavia. ${ }^{8}$ Of the roughly 10,000 jellyfish species, there are approximately 100 that comprise the majority of human envenomations. ${ }^{9}$ The sea nettle (Chrysaora quinquecirrha), for example, is widely distributed in temperate and tropical waters and is known to sting humans. The Portuguese man o' war (Physalia physalis) (not a true jellyfish but a hydroid colony) is one of the largest Coelenterates with tentacles that can reach up to $30 \mathrm{~m}$ in length. The deadliest and most venomous of coelenterates is the box jellyfish or sea wasp of Australia. ${ }^{10,11}$ Another Australian jellyfish, Carukia barnesi, also produces a devastating envenomation known as Irukandji syndrome. ${ }^{12,13}$ Studies have found that climate change will not only affect jellyfish in their native environments but may also lead to invasion into new areas.

Recent evidence is accumulating that jellyfish populations have increased in many regions of the world. ${ }^{14,15}$ These populations, however, undergo large, worldwide oscillations with approximately 20-year periodicity, including a well-documented rise in the $1970 \mathrm{~s}^{16}$ and again in the 1990s in addition to smaller cyclical oscillations. ${ }^{17}$ Their unpredictable reproductive and lifecycles can lead to blooms with spatial and temporal variability in abundance, making populations difficult to estimate. One recent study represents the first rigorous demonstration that jellyfish populations are increasing in coastal ecosystems worldwide, although it may be too early to conclude definitively (Figure 1). ${ }^{15}$ Other time- 
series investigations have shown major changes in jellyfish abundance and statistical links with climatic indices. $^{14,17-21}$

Proposed climate change factors affecting jellyfish abundance and distribution include changes in temperature, salinity, $\mathrm{pH}$, water currents, weather anomalies, predator-prey interactions, and species competition (Figure 2; Figure 3). ${ }^{14,17-19,22}$ Warmer temperatures were related to large population sizes in subtropical, temperate, and subarctic environments. ${ }^{17}$ Experiments on temperate species show greater and more rapid production of medusa and accelerated growth at warmer temperatures. ${ }^{23,24}$ Jellyfish biological reactions to increasing temperatures include increased egg (ephyrae) production ${ }^{17,23}$ and accelerated asexual budding. ${ }^{25}$ Additionally, within appropriate ranges for an organism's functioning, low temperatures slow and high temperatures accelerate metabolism and reproductive activity. ${ }^{17}$ Specifically, higher temperatures accelerated Chrysaora pacifica and Cyanea nozakii polyp formation and increased their food supply leading to a population increase in warmer waters. ${ }^{25}$ Purcell $^{5}$ found that the abundance of 11 out of 15 temperate jellyfish species reviewed increased as waters warmed, and Gibbons and Richardson demonstrated that jellyfish abundance were temperature dependent, with more occurring in warmer years. ${ }^{20}$

Increasing temperatures also result in longer reproductive seasons. ${ }^{17}$ Crysaora hysoscella, for example, appears earlier and is present until later in accordance with increased mean summer temperature. As a result, seasonal presence is now twice as long in their typical geographic locations, ${ }^{26}$ increasing the potential for human encounters. Furthermore, warmer winter seasons cause some typically dormant species to become active. $^{17}$ Studies with Aurelia aurita confirm that increased winter temperatures cause jellyfish to appear earlier in the year. ${ }^{26}$ In addition, rising temperatures also cause increases in flagellate populations, an important jellyfish food source that may be contributing to increased jellyfish populations. $^{23}$

Climate change may also alter ocean currents, evaporation rates, and rainfall patterns, ultimately increasing the variance of ocean salinity, while increases in atmospheric carbon dioxide increase ocean acidity. ${ }^{27-29}$ The effects of changing salinity on jellyfish populations has mixed evidence in the literature from no effect to increasing numbers. ${ }^{23-25,30,31}$ In the Black Sea, for example, pollution has produced low salinity, eutrophication, and alterations of the natural environment potentiating jellyfish numbers. $^{32}$ Increased atmospheric carbon dioxide concentrations dissolve into the oceans resulting in ocean acidification that alters the carbonate balance. Unlike most marine life, jellyfish increase as $\mathrm{pH}$ declines. ${ }^{31}$ Jellyfish are less affected by ocean acidification because they have no calcium carbonate components in their body plan. Acidification can contribute to overall ecosystem degradation (eg, rising temperatures, stratification of water layers, and eutrophication), allowing the more adaptable jellyfish to outcompete others at its trophic level (such as plankton and other fish).

Additionally, jellyfish populations tend to respond positively to climate-induced extremes. For example,

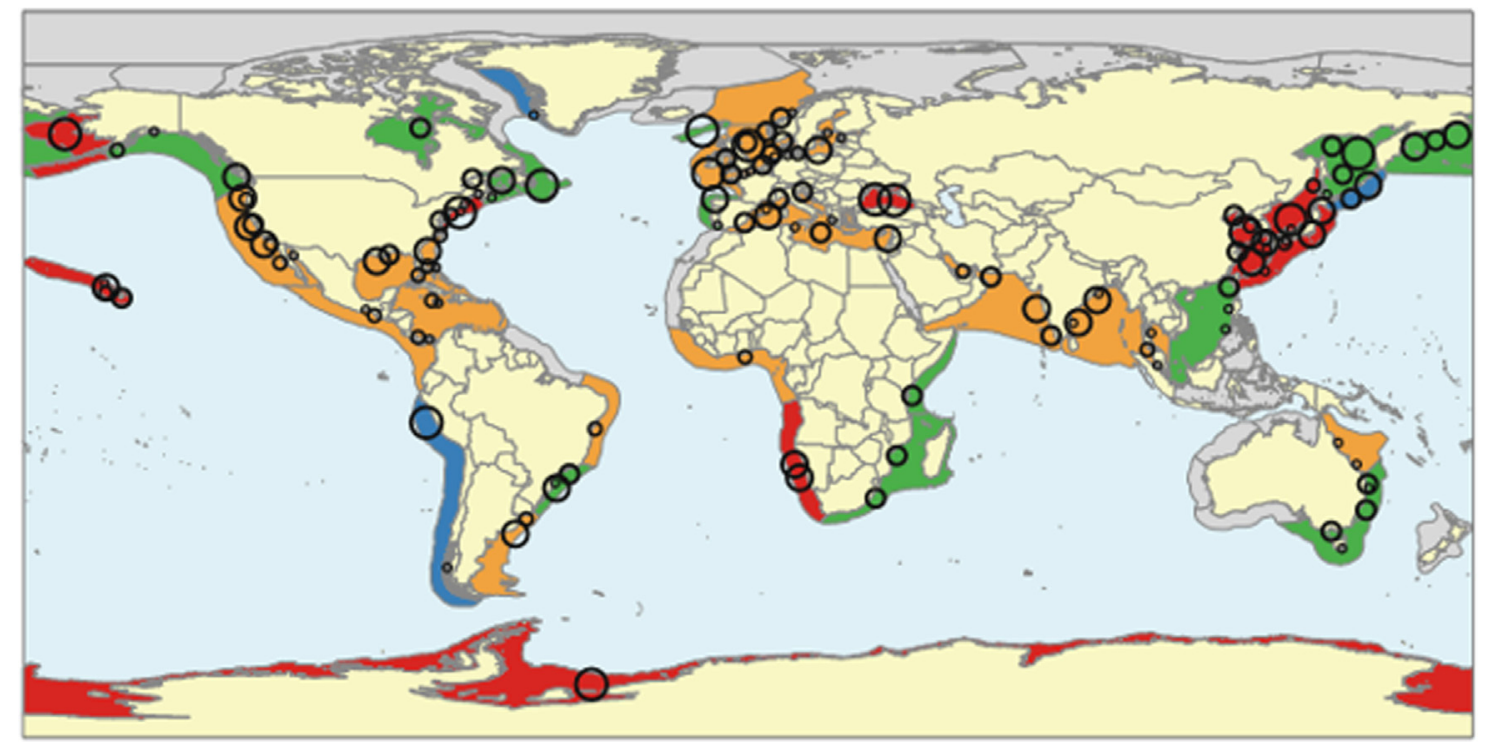

Figure 1. Map of population trends of native and invasive species of jellyfish. Red, increase (high certainty); orange, increase (low certainty); green, stable/variable; blue, decrease; gray, no data. Circles represent discrete chronicles with relative sizes reflecting the confidence index. ${ }^{15}$ Used with permission. 


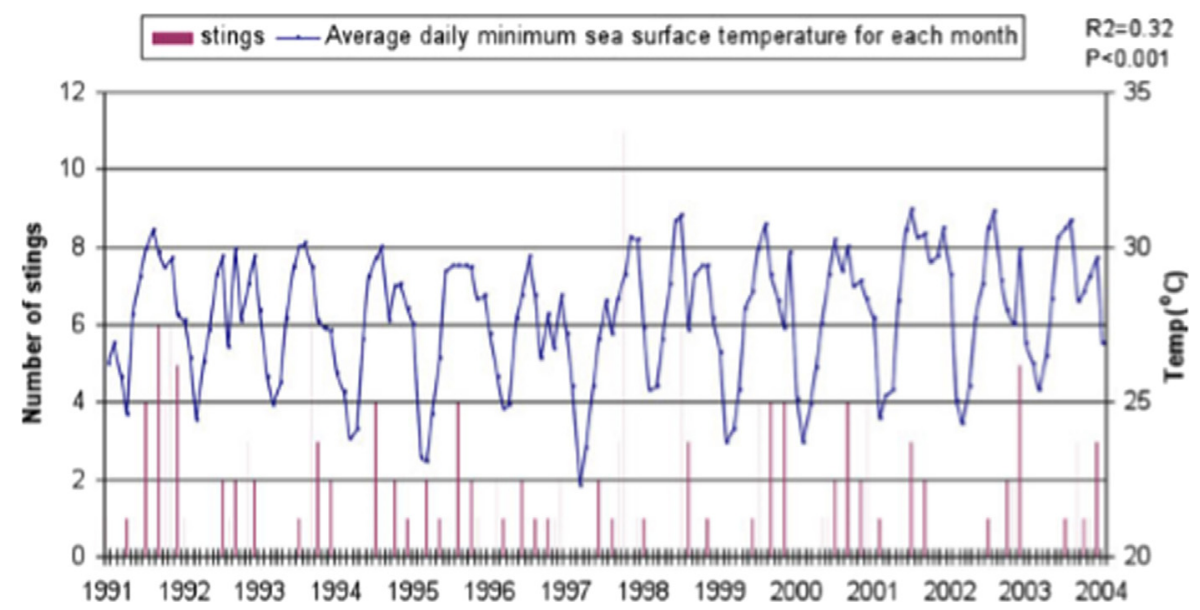

Figure 2. Monthly Chironex fleckeri stings and average daily minimum sea surface temperature, Darwin harbor, April 1991 to May $2004{ }^{23}$ Used with permission.

increases in jellyfish populations may be related to North Atlantic Oscillation (NAO), El Niño Southern Oscillation, and Pacific Decadal Oscillation, ${ }^{30,33,34}$ all climatic oscillations that occur sporadically but predictably with associated changes in temperature, sea surface temperature, salinity, upwelling, and rainfall patterns. Jellyfish numbers in the North Sea are positively related to the NAO, ${ }^{31}$ and a recent study in Peru postulated that jellyfish numbers may be positively correlated with the effects of El Niño Southern Oscillation. ${ }^{35}$ These natural oscillations are thought to be exacerbated by climate change. $^{36}$

Climate change may also cause negative effects on jellyfish and their competition. ${ }^{23,24,37,38}$ Both low and high temperatures can disable enzymes and transport systems, which physiologically restricts organisms to their adapted temperatures. ${ }^{17,39}$ Decrease in native populations of jellyfish may occur with higher temperatures once they reach their metabolic threshold since they are unable to tolerate further warming (upper limit $34-35^{\circ} \mathrm{C}$ for many species). ${ }^{17}$ These metabolic restrictions may lead to major shifts in community structure and dynamics as some species invade and replace others.

Invasion of nonindigenous populations frequently involves species of jellyfish. In one investigation, $47 \%$ of marine systems studied involved invasive jellyfish. ${ }^{15}$ Invasive migration is directly related to increased temperatures and indirectly due to associated changes in salinity. ${ }^{17,23,40,41}$ These conditions favor invasive species over native. ${ }^{42,43}$ Examples of invasive jellyfish

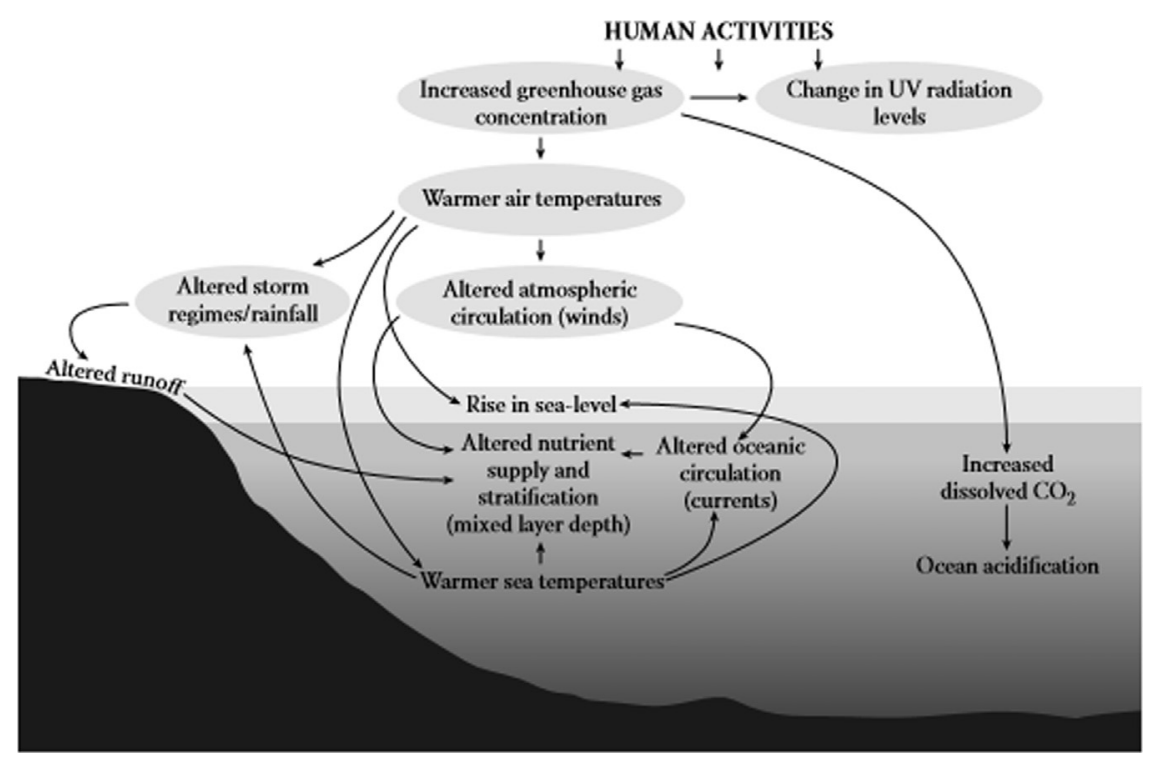

Figure 3. Important physical and chemical changes in the atmosphere and oceans as a result of climate change. ${ }^{46}$ Used with permission. 
species include Rhopilema nomadica, which have been increasingly abundant in the eastern Mediterranean over the past 2 decades. ${ }^{32}$ They are now considered an environmental hazard and increased human encounters have been reported. In the San Francisco Bay area and Chesapeake Bay, a new estuarine hydromedusae that thrives in low salinity environments has been described. $^{24,32}$

With the potential increase of jellyfish population concentrations and expanded distributions, the venomous jellyfish-human encounters are also changing. Increasing populations of Portuguese man o' war have been reported in the Mediterranean Sea, which is likely due to recent alterations in NAO linked to climate change. ${ }^{44}$ Increase in bluebottle jellyfish Pelagia noctiluca sightings correlate with increased water temperatures in the Tasmanian Sea, closer to the region of southern Sydney. ${ }^{21,45}$

The box jellyfish Chironex fleckeri and the species complex known as Irukandji have been responsible for increasing human fatalities and recreational beach closures. $C$ fleckeri sting numbers have been associated with SST increases. ${ }^{23}$ SST appears to be the determining factor signaling the "arrival" of $C$ fleckeri each year. The rising SST leads to an earlier annual arrival of $C$ fleckeri. The general global warming trend here has been exacerbated by the strengthening of the warm southward-flowing East Australian current over the past 60 years, a situation that appears to be caused by altered circulation patterns in response to climate change. ${ }^{46}$ There is growing concern that box jellyfish might expand southward toward more populated areas, with negative repercussions for the local tourist industry. ${ }^{47}$

Potential increases in jellyfish encounters should be met with heightened awareness, advanced life support measures, and available antivenom. In most cases of jellyfish stings, treatment includes tentacle removal, application of vinegar (4-8\% acetic acid by volume) for box jellyfish, and hot water immersion $\left(45^{\circ} \mathrm{C}\right.$ for 20 min) for bluebottle jellyfish stings. Advanced life support is essential for severe marine envenomation that results in cardiac collapse or paralysis. Irukandji syndrome causes severe generalized pain from autonomic excess, which may require large amounts of analgesia. Rarely, myocardial depression and pulmonary edema occur. Box jellyfish (C fleckeri) stings often result in painful skin welts. Fatalities are uncommon, but may occur within 5 to $20 \mathrm{~min}$ of the sting. This rapid onset of neuro and cardiotoxicity suggests that antivenom should be readily available and administered early in the clinical course. $^{48}$ Therefore, adequate supplies of antivenom are required in regions with increasing potential human encounters.

\section{VENOMOUS FISH}

There are more than 250 species of venomous fish, consisting mostly of shallow water reef or inshore fish found near the coast. Stingrays are the most commonly encountered venomous fish, with more than 2000 stings reported annually, and 11 species found in US coastal waters. When frightened or stepped on, the stingray thrusts its spiny tail upward and forward, driving its venom-laden stinging apparatus into the foot or lower extremity of the victim. ${ }^{49}$ While we found a paucity of data in the literature regarding the effects of climate change on stingray distribution and human encounters, 1 report documents that new encounters with the roughtail stingray Dasyatis centroura have been noted in the Atlantic archipelago of the Azores. ${ }^{50}$

In this same study, the long-spine porcupinefish Diodon holacanthus was also noted for the first time in the Azores attributed to recent changes in climate. Like the puffer fish, this fish contains tetrodotoxin, which can result in life-threatening neurotoxicity and respiratory depression if ingested. In addition to stingrays and porcupinefish, other types of venomous fish include lionfish (Pterois), scorpion fish (Scorpaena), and stonefish (Synanceja), which are listed in increasing order of venom toxicity. Although more common in tropical waters of the Indo-Pacific, these fish are found in the shallow water reefs of the Florida Keys, Gulf of Mexico, southern California, and Hawaii.

\section{Lionfish}

Lionfish (Pterois volitans [red lionfish] and Pterosis miles [devil firefish]) originate from the Indo-Pacific. These ornate yet aggressive fish have become increasingly popular as aquarium pets ${ }^{51,52}$ and were introduced into the West Atlantic via the aquarium trade in the late 1980s when pet fish were released into the ocean. Over the past decade, populations of lionfish have been increasing along the Atlantic coast of the United States ${ }^{53}$ and are currently in the process of colonizing the entire Caribbean basin. ${ }^{54,55}$ The life cycle and behavioral traits such as early age at maturity, high fecundity, and yearround breeding have allowed a rapid population growth and drastic effects on recipient communities. ${ }^{54}$ Ecologically, lionfish possess a unique appearance and hunting strategy: venomous spines that discourage predation by local predators, high fecundity, and a wide range of habitat preferences. ${ }^{57-63}$ These traits, along with a generalist diet, likely contribute to their invasion success and have resulted in the reduced abundance, recruitment, and diversity of native prey fishes. ${ }^{56,64-68}$ 
The limits of the lionfish's introduced range, currently determined by the $10^{\circ} \mathrm{C}$ isotherm, is set to expand as the isotherm shifts north and south in the 2 hemispheres due to climate change. ${ }^{54}$ Many aspects of lionfish life history and behavior are expected to be temperature-dependent. A shorter pelagic larval duration is linked to dispersal potential, which leads to less drifting and less spreading. However, this reduction is more than an order of magnitude smaller than the current annual rate of their expansion in the Caribbean. The prey consumption rate, an important determinant of impacts of lionfish on native prey, is exacerbated by the current imbalance between lionfish consumption and prey production rates.

Using projections of future ocean temperatures and salinities, one study explored potential lionfish habitat through the year 2100 under conditions of anthropogenic climate change. ${ }^{68}$ Without culling efforts, the spatial extent of suitable year-round lionfish habitat is expected to increase $45 \%$ on the southeast United States continental shelf (SEUSCS) during the 21st century, covering $90 \%$ of the region. In the summer months, they are now found as far north as New York. The SEUSCS is expected to warm substantially over the coming decades, likely allowing lionfish to permanently invade structured benthic habitat on the continental shelf of Georgia and the Carolinas, but not the continental shelf of the northeast United States. Winter temperatures are currently too cold for the fish to tolerate, due to convergence of the Gulf Stream and Northern Bight, with the warmer Gulf Stream currents not flowing that far north. Elsewhere in the Atlantic Ocean, lionfish Pterois miles have spread rapidly and colonized almost the entire south eastern coast of Cyprus within 1 year's time. ${ }^{69}$ Habitat expansion by this invasive predator is likely to occur regardless of whether future emissions are more similar to the RCP 4.5 or 8.5 climate scenarios; however, the magnitude of continued invasion can be mitigated by large-scale decreases in greenhouse-gas emissions.

In terms of human-lionfish contact, lionfish presence has strongly progressed in regions of the Caribbean and Atlantic seacoast resulting in increasing envenomation cases (Figure 4). ${ }^{60}$ Recommended management includes immersion of the affected body part in hot water at 35 to $40^{\circ} \mathrm{C}$ for 60 to $90 \mathrm{~min}$, analgesics, and antibiotics. ${ }^{70}$ Regarding other fish envenomations, stonefish (Synanceia horrida) envenomation also requires hot water soaks along with stonefish-specific antivenom administration in severe cases. ${ }^{71}$ Penetrating marine injuries from other venomous fish like stingrays can cause significant trauma depending on location of the injury. Large and unclean wounds require adequate irrigation and debridement, including stingray spine removal, to avoid delaying healing and secondary
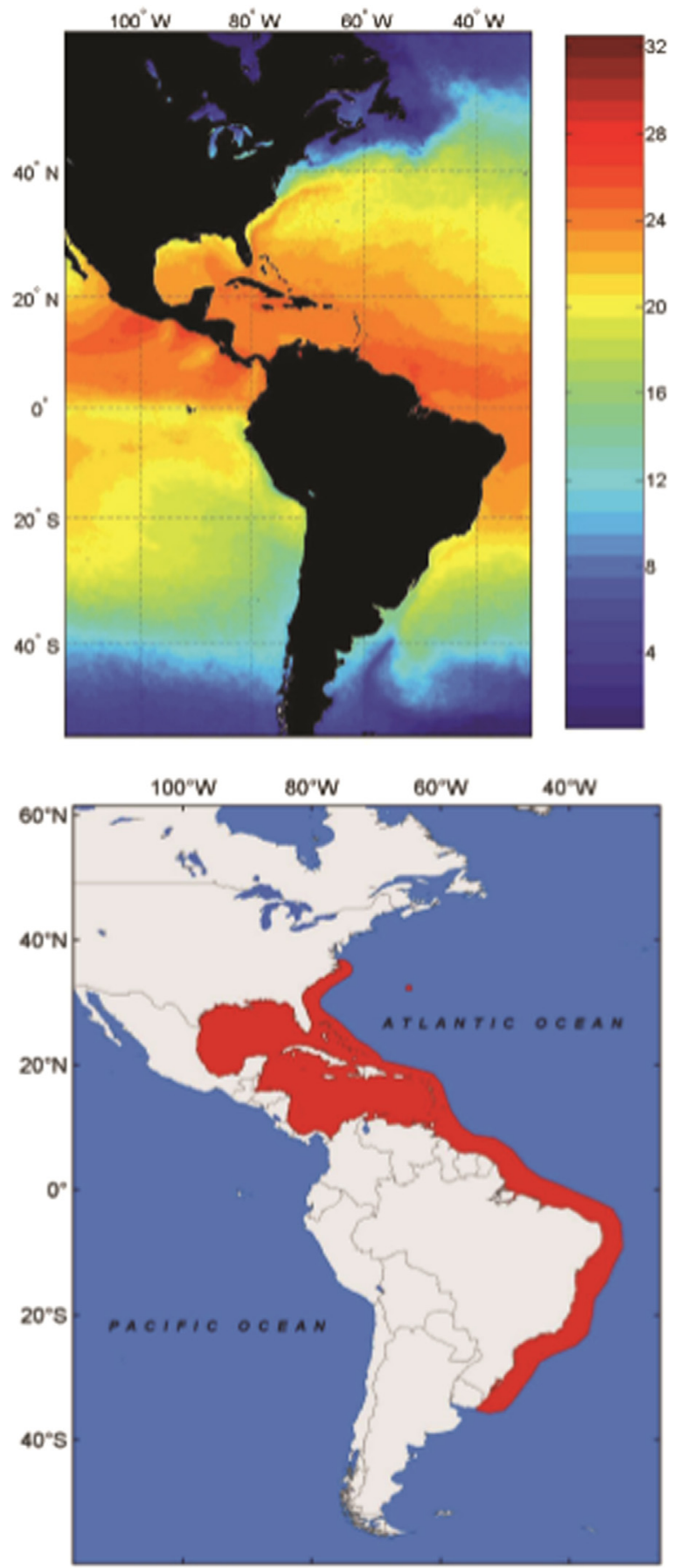

Figure 4. Average annual sea surface temperatures and potential future range of lionfish based on the lethal thermal minimum of $10^{\circ} \mathrm{C}$. Source: Biology, Ecology, Control and Management of the Invasive Indo-Pacific Lionfish. ${ }^{60}$ Used with permission.

infection. $^{12}$ Recreational scuba divers, tourists, and commercial fishermen may be naïve to the dangerous stings of these fish; therefore, venomous encounters are likely to increase. 


\section{CROWN-OF-THORNS STARFISH}

Crown-of-thorns starfish (COTS), Acanthaster planci, are a species of echinoderm found in tropical waters throughout the Indo-Pacific. ${ }^{72}$ The dorsal region of these starfish is covered in toxic, thorn-like spines, giving them their common name. In their adult stage, COTS feed on living coral polyps and can decimate coral reefs when at high numbers. It is estimated that about $50 \%$ of the coral loss in the Great Barrier Reef off the coast of Australia can be attributed to COTS outbreaks. ${ }^{73}$ These COTS outbreaks are unpredictable and are just beginning to be understood by the scientific community. Major outbreaks have been reported in the last several decades in reefs throughout their range including Australia (Great Barrier Reef), ${ }^{74}$ French Polynesia, ${ }^{72}$ Papua New Guinea, $^{75}$ and Indonesia. ${ }^{76}$

Although many factors may potentially be linked to these COTS outbreaks including reef characteristics and position, ocean currents, and direct anthropogenic stressors, direct links to climate change have also been found. One study found that in addition to influxes of nutrients from human activities, increased temperature also affected the larval development of COTS. A $2^{\circ} \mathrm{C}$ increase in temperature sped up larval development by 4.2 to 4.9 times over a 10-day period. ${ }^{72}$ Ocean acidification may also play a role in increased COTS densities. Lower ocean $\mathrm{pH}$ weakens the structure and defenses of crustose coralline algae, which are an integral food source for juvenile COTS, while leaving the sea stars themselves unaffected. Juveniles grown at a lower $\mathrm{pH}$ grew faster and were overall more successful. ${ }^{77}$

The greatest risk to humans is the COTS's iconic toxic spines. The spines themselves can puncture skin causing pain, inflammation, and possible infection. ${ }^{78}$ Additionally, the spines house toxins such as phospholipases $\mathrm{A}_{2},{ }^{79}$ deoxyribonucleases II, ${ }^{80}$ and an anitcoagulant factor ${ }^{81}$ that can cause further complications. Effects on the liver including potential hepatic toxicity have been reported in humans $^{82}$ and while rare, anaphylactic shock leading to mortality has also been reported. ${ }^{83}$ Treatment generally includes wound irrigation, spine removal, and antibiotic coverage for marine microbes such as Vibrio species. As climate change continues to exacerbate COTS outbreaks, the potential for contact with humans may also increase.

\section{SEA SNAKES}

Sixty species of sea snakes are currently recognized, many of which are highly venomous, although venom injection is rare when bites occur. ${ }^{84}$ Sea snakes primarily inhabit tropical and subtropical regions of the Indian and Pacific Oceans; ${ }^{85}$ however, recent reports have identified sea snakes outside of their distribution range, including the yellow-bellied sea snake (Hydrophis platurus) in California, ${ }^{86}$ black-banded sea kraits (Laticauda semifasciata) and blue-lipped sea kraits ( $L$ laticaudata) in Japan, ${ }^{87}$ L semifasciata and H platurus in Russia, ${ }^{88}$ and $L$ semifasciata in Korea. ${ }^{89}$ The expansion of $L$ semifasciata distribution has been reported multiple times in part due to the fact that the species' venom is 10 times stronger than a cobra ${ }^{90}$ (Figure 5). ${ }^{91}$ The causes of these species' expanding distribution zones have been theorized, with climate change playing a role.

Recent studies have recognized that several species of sea snakes cannot maintain a water balance and dehydrate without a source of freshwater, and as a result fresh water sources and local precipitation are key in species distribution. $^{92,93}$ One observational study in the coastal waters of Taiwan demonstrated a positive correlation between the number of amphibious sea snakes and local cumulative rainfall over a 6-y period with mean abundance in wet years nearly threefold greater than in dry years. ${ }^{94}$ Given the anticipated precipitation pattern changes due to climate change, future distribution may be drastically altered, including extinctions if climate change significantly reduces precipitation in this region as climate models have predicted. ${ }^{9.5}$

Another observational study tested the genetic origin of 12 black-banded sea kraits (L semifasciata) found around southern South Korea, a location historically outside their established distribution zone. ${ }^{96}$ Genetic testing determined that all 12 snakes originated from the Taiwan-Ryukyu region southward. The researchers hypothesized that the snakes' northward migration was affected by the increased ocean temperatures as well as the affect of climate change on local currents and prey distribution.

Changing population distributions for sea snakes may alter the human populations exposed to venomous bites. For example, the northward dispersal of $L$ semifasciata into Korean waters may require education of coastal populations to the dangers and management of sea snake bites. ${ }^{96}$ Treatment of sea snake envenomation includes rescuing the victim from the water to prevent drowning, airway management, ventilatory support, and timely sea snake antivenom administration. Although increasing in certain geographic regions like Korea, Hawaii, and California, on a global scale, sea snake populations have been found to be declining due to multiple factors including climate change, deterioration of habitat quality, and overexploitation. ${ }^{96-98}$ 


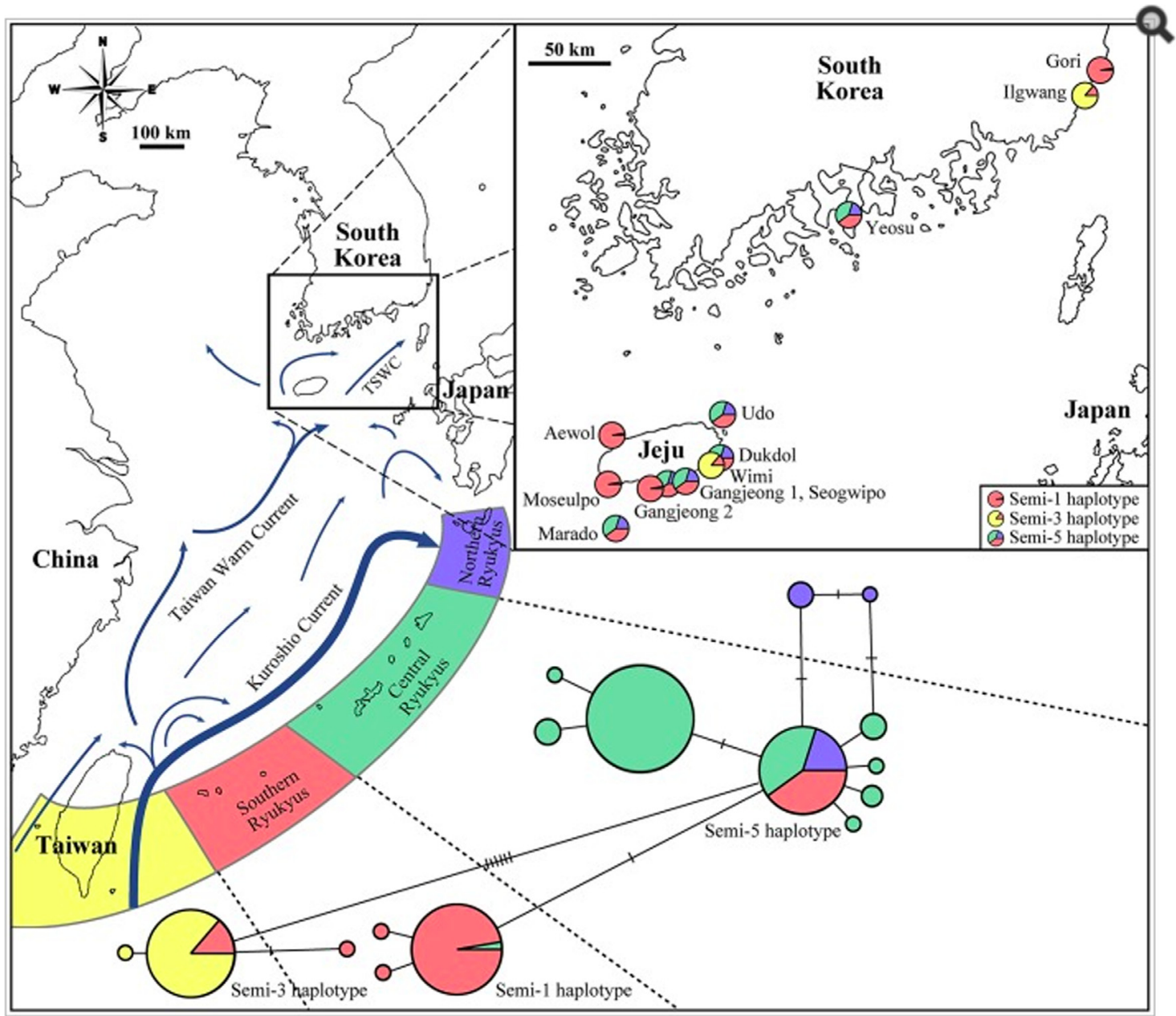

Figure 5. Haplotype network of Laticauda semifasciata from East Asia. ${ }^{91}$ Used with permission.

\section{AMPHIBIANS}

Globally, amphibian populations are declining dramatically with more than $32 \%$ of species listed as vulnerable, endangered, or critically endangered by the International Union for Conservation of Nature. Some estimate that as many as 122 species have gone extinct since $1980 .{ }^{99}$ The largest instances of die-offs and population declines of frogs and toads are occurring in Australia, Central America, and the western United States. ${ }^{100-102}$ While habitat destruction and degradation along with disease are considered the biggest and most direct causes of this dramatic decrease, other factors such as contaminants, introduced predators, and climate change also make the list. $^{99,100}$ To our knowledge, very little literature exists on the effects of climate change on venomous species of frogs (poison dart frogs specifically); however, their range over Central and South America is a hotbed of amphibian extinction and research attempting to link this phenomenon with climate change. ${ }^{103,104}$

\section{Poisonous dart frogs}

Poisonous "dart frogs" are so called due to South and Central American indigenous use of their curare-like toxic secretions to poison the tips of blow darts. Of the over 170 species, only 4 from the genus Phyllobates are considered toxic. Many poison dart frogs secrete lipophilic alkaloids such as batrachotoxin, epibatidine, and histrionicotoxin through their skin. These alkaloids serve as a chemical defense against predators such as snakes and birds.

The negative effects of climate change on amphibian populations in general have been a major area of study. As a group, amphibians are incredibly sensitive to external conditions and therefore particularly susceptible to changes in their environment, particularly rapid ones. ${ }^{105}$ Specifically, changes in temperature and moisture could seriously and directly affect the biology and physiology of amphibians. ${ }^{106,107}$ Water availability is extremely important for the reproductive 
cycle of most amphibious species as well as for the survival of adult individuals. Temperature also plays a role in gametogenesis and larval growth rates. ${ }^{100}$ Additionally, spring temperatures are vital in determining the timing of breeding as well as hibernation cycles in many species. ${ }^{100,108}$ These shifts in phenology along with other stressors associated with climate change such as longer dry seasons, drier soil, greater variation in rainfall, and more severe weather events could be direct threats to the survival of the species. ${ }^{100,106}$ If climate change cannot be explicitly linked to amphibian population declines now, these changes will certainly have negative effects into the future. ${ }^{99,105,106}$

Other, more indirect effects of climate change on amphibian populations have also been debated. In the Monteverde region of Costa Rica, about half of the 50 species found in the area had disappeared by 1990. ${ }^{102}$ This die-off was attributed to a disease known as chytridiomycosis caused by the fungus Batrachochytrium dendrobatidis, which is itself susceptible to changes in the external environment and also found in other areas of the world including Australia and the United States that have experienced massive amphibian die-offs. ${ }^{101,104,107}$ In a controversial paper, Pounds et al found that outbreaks of the disease could be correlated with years of higher temperatures and linked the lethality of the fungus with climate change. ${ }^{104}$ This fungus has been found to infect species of poison dart frog. ${ }^{109}$ However, this paper has largely been refuted in more recent years as a correlation rather than causation and the disease now modeled as an introduced pathogen rather than a "climate-linked epidemic hypothesis." $101,107,108$

For poison dart frogs, the environmental changes associated with climate change could still serve to exacerbate weakened amphibious species and indirectly lead to population declines. Additionally, although amphibians are generally immobile organisms, adding to the threat of climate change as they struggle to escape inhospitable conditions, some studies have shown that they are capable of elevation range changes in response to changing temperatures. ${ }^{99,110}$ Although the link may be tenuous due to lack of current data, amphibian populations have been steadily and dramatically declining in recent years and climate change poses a serious threat if not now, then in the future to this fragile group of organisms.

The most toxic of poison dart frog species is the golden poison frog Phyllobates terribilis, which has enough toxin on average to kill 10 to 20 humans. Unless intentionally handled or ingested, the human health implications from these rare species are minimal and encounters will likely decline as overall frog numbers decrease.

\section{Discussion}

The effects of climate change on these species through temperature alteration and other climatic shifts will potentially affect commercial industries, travel, tourism, and human health. Current warming trends are causing venomous creatures to expand poleward and tropical venomous creatures may soon encounter population centers in Europe, North and South America, and Australia with regional hotspots and problematic blooms despite potentially no global increase in abundance. Conversely, these changes are also causing local and global declines, even to the point of extinction, for some species that are not able to expand their ranges.

Most marine stings result in minor clinical symptoms and do not require medical attention. A majority of marine injuries are caused by jellyfish stings and penetrating injuries from spiny fish, stingrays, or sea urchins. ${ }^{12}$ Severe and systemic marine envenoming are less common, and include box jellyfish stings, Irukandji syndrome, major stingray trauma, and blue-ringed octopus envenoming. (In our systematic review, no literature linking blue-ringed octopi to climate change was found.) Limited supplies of antivenoms are available for treating envenomation by certain sea snakes, stonefish, and box jellyfish. ${ }^{47,111}$

In regards to human health, perhaps more important than change in abundance are the changes in phenology and distribution; therefore, unexpected blooms are expanding and certain species are appearing in places and seasons that have not been previously described. As geographic location and timing are altered, this can result in more human-animal contact and encounters in particular regions of the world. ${ }^{32}$ For example, as winter temperatures have increased over the last decades, Aurelia aurita has increased worldwide and this species of jellyfish is now occurring significantly earlier in the year. ${ }^{26}$ Various human encounters with jellyfish have increased including an increase in the numbers of fatal stings, beach closures, decreased productivity of fish farms, the clogging of intakes in coastal power and desalination plants, and negative effects on the shipping industry. ${ }^{15,23}$ For lionfish and COTS, increased densities as the animals become more abundant could also lead to more exposures. Both species dominate areas such as reefs that are traditionally tourist attractions. Snorkelers, divers, and beachcombers may be particularly susceptible. Regions naïve to the stinging properties of the fish's and starfish's dorsal spines could be particularly at risk. Similarly, the human 
health implications for neurotoxic sea snakes could include more frequent encounters and potential envenomation as their ranges shift. Particularly in regions where these species were not found previously, the results could be lethal if proper treatment (eg, antivenom) is not immediately available. It is therefore vitally important to track the movements of these marine creatures and educate healthcare workers in these newly colonized areas as to the proper treatments in case of human contact.

In contrast, amphibians show the alternative effect of climate change. Globally, species in all taxa are going extinct at unprecedented rates in what many are calling the "sixth mass extinction" due to anthropogenic pressure including climate change. ${ }^{112}$ This rapid decline is particularly pronounced in amphibians, but other species are also negatively affected. For example, although sea snakes are expanding their ranges and coming into contact with humans in unprecedented locations, globally their populations are in decline. The interplay between venomous species and climate change can be complex and examining not just species abundances, but also range and phenological shifts and their potential impacts on human health will be important moving forward.

\section{LIMITATIONS}

Many important venomous marine and amphibious species were not described in this review due to little or a lack of published studies. Specifically, future investigations focusing on stingrays, certain poisonous fish (eg, scorpionfish and stonefish), and other toxic species such as the blue-ringed octopus would provide further insight in to the effects of climate change on their habitats, distribution, and potential human encounters.

Of the studies included in this review article, the authors acknowledge that many of the papers were based on future modeling, which are speculative in nature and based on current-day information and projected data.

\section{Conclusion}

For those who travel and venture into the wilderness with intentions of preserving natural surroundings and resources, increased awareness and education regarding the potential effects of climate change on venomous creatures are important. Our review of the literature investigating the effect and forecasts of climate change on venomous aquatic and amphibious creatures has demonstrated that temperature extremes and changes to climatic norms could have a potentially dramatic effect on these toxicological organisms. In some cases, rising temperatures, weather extremes, and shifts in seasons will increase poisonous population numbers, particularly with certain marine creatures like jellyfish and crown-ofthorns sea stars. Range expansions by lionfish and sea snakes are also projected to occur. Human encounters with these types of creatures are likely to increase, resulting in potential human morbidity and mortality. The effects of climate change on these species through temperature alteration and rising coastal waters will potentially affect commercial industries, travel, and tourism.

Others, particularly amphibians, are declining rapidly due to their sensitivity to any temperature change or subtle alterations in the stability of their environment. If temperatures continue to rise and fall to record levels over the next decades and century, it is predicted that many of these once plentiful and critically important animals to the ecosystem will suffer, populations will dramatically decline, and geographic distributions will shrink. Several species may become endangered and eventually go extinct resulting in a global decline of biodiversity.

Author Contributions: Literature review (RN, IN, TE); analysis of literature (RN, IN, TE); drafting of manuscript (IN, TE); critical revision of manuscript (RN, IN, TE); approval of final manuscript (RN, IN, TE).

Financial/Material Support: None

Disclosures: None

\section{References}

1. NOAA National Centers for Environmental Information, January. State of the Climate: Global Climate Report Annual-2017.

2. Ciais P, Sabine C, Bala G, Bopp L, Brovkin V, Canadell J, et al. Carbon and other biogeochemical cycles. In: Stocker TF, Qin D, Plattner G-K, eds. Climate Change 2013: The Physical Science Basis. Contribution of Working Group I to the Fifth Assessment Report of the Intergovernmental Panel on Climate Change. Cambridge, UK: Cambridge University Press; 2013:465-570.

3. Huang B, Thorne PW, Smith TM, Liu W, Lawrimore J, Banzon V, et al. Full access further exploring and quantifying uncertainties for extended reconstructed sea surface temperature (ERSST) version 4 (v4). J Clim. 2016;29(9):3119-42.

4. Bernstein L, Pachauri RK, Reisinger A, Intergovernmental Panel on Climate Change. Climate Change 2007: Synthesis Report. Contribution of Working Groups I, II and III to the Fourth Assessment Report of the Intergovernmental Panel on Climate Change. Geneva, Switzerland: IPCC; 2008.

5. Purcell JE. Jellyfish and ctenophore blooms coincide with human proliferations and environmental perturbations. Ann Rev Mar Sci. 2012;4(1):209-35. 
6. Small C, Nicholls RJ. A global analysis of human settlement in coastal zones. J Coast Res. 2003;19(3): 584-99.

7. Erickson TB, Auerbach P. Marine envenomations and seafood poisoning. Pediatric Toxicology: Diagnosis and Management of the Poisoned Child. 1st ed. New York, NY: McGraw-Hill, Medical Pub. Division; 2005:624.

8. Henn A, Pérignon A, Monsel G, Larréché S, Caumes E. Marine envenomations in returning French travellers seen in a tropical diseases unit, 2008-13. J Travel Med. 2016;23(2): $\operatorname{tav} 022$.

9. Cegolon L, Heymann WC, Lange JH, Mastrangelo G. Jellyfish stings and their management: a review. Mar Drugs. 2013;11(2):523-50.

10. Auerbach PS. Envenomation by aquatic animals. Wilderness Medicine. 6th ed. St. Louis, MO: Elsevier/Mosby; 2012.

11. Avelino-Silva VI, Avelino-Silva T. Evolution of a jellyfish sting. N Engl J Med. 2011;365(3):251.

12. Berling I, Isbister G. Marine envenomations. Aust Fam Physician. 2015;44(1):28-32.

13. Lippmann JM, Fenner PJ, Winkel K, Gershwin LA. Fatal and severe box jellyfish stings, including Irukandji stings, in Malaysia, 2000-2010. J Travel Med. 2011;18 (4):275-81.

14. Brodeur RD, Decker MB, Ciannelli L, Purcell JE, Bond NA, Stabeno PJ, et al. Rise and fall of jellyfish in the eastern Bering Sea in relation to climate regime shifts. Prog Oceanogr. 2008;77(2):103-11.

15. Brotz L, Cheung WWL, Kleisner K, Pakhomov E, Pauly D. Increasing jellyfish populations: trends in large marine ecosystems. Hydrobiologia. 2012;690(1):3-20.

16. Condon RH, Duarte CM, Pitt KA, Robinson KL, Lucas $\mathrm{CH}$, Sutherland KR, et al. Recurrent jellyfish blooms are a consequence of global oscillations. Proc Natl Acad Sci. 2013;110(3):1000-5.

17. Purcell JE. Climate effects on formation of jellyfish and ctenophore blooms: a review. J Mar Biol Assoc United Kingdom. 2005;85(3):461-76.

18. Lynam CP, Lilley MKS, Bastian T, Doyle TK, Beggs SE, Hays GC. Have jellyfish in the Irish Sea benefited from climate change and overfishing? Glob Chang Biol. 2011;17(2):767-82.

19. Molinero JC, Ibanez F, Souissi S, Buecher E, Dallot S, Nival P. Climate control on the long-term anomalous changes of zooplankton communities in the Northwestern Mediterranean. Glob Chang Biol. 2008;14 (1):11-26.

20. Gibbons MJ, Richardson AJ. Patterns of jellyfish abundance in the North Atlantic. Hydrobiologia. 2009;616 (1):51-65.

21. Licandro P, Conway DVP, Daly Yahia MN, Fernandez de Puelles ML, Gasparini S, Hecq JH, et al. A blooming jellyfish in the northeast Atlantic and Mediterranean. Biol Lett. 2010;6(5):688-91.

22. Richardson AJ, Bakun A, Hays GC, Gibbons MJ. The jellyfish joyride: causes, consequences and management responses to a more gelatinous future. Trends Ecol Evol. 2009;24(6):312-22.

23. Jacups SP. Warmer waters in the Northern TerritoryHerald an earlier onset to the annual chironex fleckeri stinger season. Ecohealth. 2010;7(1):14-7.

24. Meek MH, Wintzer AP, Wetzel WC, May B. Climate change likely to facilitate the invasion of the non-native hydroid, Cordylophora caspia, in the San Francisco estuary. PLoS One. 2012;7(10):e46373.

25. Thein H, Ikeda H, Uye S. Ecophysiological characteristics of podocysts in Chrysaora pacifica (Goette) and Cyanea nozakii Kishinouye (Cnidaria: Scyphozoa: Semaeostomeae): effects of environmental factors on their production, dormancy and excystment. J Exp Mar Bio Ecol. 2013;446:151-8.

26. Van Walraven L, Langenberg VT, Dapper R, Witte JI, Zuur AF, van der Veer HW. Long-term patterns in 50 years of scyphomedusae catches in the western Dutch Wadden Sea in relation to climate change and eutrophication. J Plankton Res. 2015;37(1):151-67.

27. Held I, Soden BJ. Robust response of the hydrological cycle to global warming. J Clim. 2006;19(21): 5686-99.

28. Durack PJ, Wijffels SE, Matear RJ. Ocean salinities reveal strong global water cycle intensification during 1950 to 2000. Science. 2012;336(6080):455-8.

29. Ummenhofer CC, Meehl GA. Extreme weather and climate events with ecological relevance: a review. Philos Trans R Soc B Biol Sci. 2017;372(1723):20160135.

30. Lynam CP, Hay SJ, Brierley AS. Interannual variability in abundance of North Sea jellyfish and links to the North Atlantic Oscillation. Limnol Oceanogr. 2004;49(3): 637-43.

31. Attrill MJ, Wright J, Edwards M. Climate-related increases in jellyfish frequency suggest a more gelatinous future for the North Sea. Limnol Oceanogr. 2007;52(1):480-5.

32. Mills CE. Jellyfish blooms: Are populations increasing globally in response to changing ocean conditions? Hydrobiologia. 2001;451(1/3):55-68.

33. Raskoff KA. The impact of El Niño events on populations of mesopelagic hydromedusae. Hydrobiologia. 2001;451(1/3):121-9.

34. Anderson P, Piatt J. Community reorganization in the Gulf of Alaska following ocean climate regime shift. Mar Ecol Prog Ser. 1999;189:117-23.

35. Quiñones J, Mianzan H, Purca S, Robinson KL, Adams GD, Marcelo Acha E. Climate-driven population size fluctuations of jellyfish (Chrysaora plocamia) off Peru. Mar Biol. 2015;162(12):0.

36. Chevin L-M, Hoffmann AA. Evolution of phenotypic plasticity in extreme environments. Philos Trans $R$ Soc $B$ Biol Sci. 2017;372(1723):20160138.

37. Vitousek PM, Antonio CMD, Loope LL, Westbrooks R. Biological invasions as global environmental change. Am Sci. 2016;84(5):468-78.

38. Vitousek PM. Beyond global warming: ecology and global change. Ecology. 1994;75(7):1861-76. 
39. Kinne O. The effects of temperature and salinity on marine and brackish water animals. II. Salinity and temperature-salinity combinations. Oceanogr Mar Biol An Annu Rev. 1984;2:281-339.

40. Cai W, Shi G, Cowan T, Bi D, Ribbe J. The response of the Southern Annular Mode, the East Australian Current, and the southern mid-latitude ocean circulation to global warming. Geophys Res Lett. 2005;32(23): L23706.

41. Ridgway KR. Long-term trend and decadal variability of the southward penetration of the East Australian Current. Geophys Res Lett. 2007;34(13).

42. Dukes JS, Mooney HA. Does global change increase the success of biological invaders? Trends Ecol Evol. 1999;14(4):135-9.

43. Stachowicz JJ, Terwin JR, Whitlatch RB, Osman RW. Linking climate change and biological invasions: ocean warming facilitates nonindigenous species invasions. Proc Natl Acad Sci USA. 2002;99(24):15497-500.

44. Prieto L, Macías D, Peliz A, Ruiz J. Portuguese Man-ofWar (Physalia physalis) in the Mediterranean: a permanent invasion or a casual appearance? Sci Rep. 2015;5:11545.

45. Draper S, Musca L, Peng Y, Wang T. Rising sea temperatures are affecting the distribution of the Bluebottle Jellyfish, Physalia utriculus. Cygnus. 2014;1:50-9.

46. Gibson RN, Atkinson RJA, Gordon JDM. Climate change and Australian marine life. In: Oceanography and Marine Biology: An Annual Review; Taylor \& Francis; 2007.

47. Poloczanska E, Babcock RC, Butler A, Hobday AJ, Hoegh-Guldberg O, Kunz TJ. Climate change and Australian marine life. Oceanogr Mar Biol. 2007;45:407-8.

48. Currie BJ. Marine antivenoms. J Toxicol Clin Toxicol. 2003;41(3):301-8.

49. Hambright D, Guss D, Smith JT. Unique case of posterior tibial tendon dysfunction after stingray strike. Foot Ankle Spec. 2016;9(3):275-8.

50. Afonso P, Porteiro FM, Fontes J, Tempera F, Morato T, Cardigos F, et al. New and rare coastal fishes in the Azores islands: occasional events or tropicalization process? J Fish Biol. 2013;83(2):272-94.

51. Aldred B, Erickson T, Lipscomb J. Lionfish envenomations in an urban wilderness. Wilderness Environ Med. 1996;7(4):291-6.

52. Vetrano SJ, Lebowitz JB, Marcus S. Lionfish envenomation. J Emerg Med. 2002;23(4):379-82.

53. Cearnal L. Red lionfish and ciguatoxin: menace spreading through western hemisphere. Ann Emerg Med. 2012;60(1):21A-22AA.

54. Côté IM, Green SJ. Potential effects of climate change on a marine invasion: the importance of current context. Curr Zool. 2012;58(1):1-8.

55. Resiere D, Cerland L, De Haro L, Valentino R, CriquetHayot A, Chabartier C, et al. Envenomation by the invasive Pterois volitans species (lionfish) in the French
West Indies-a two-year prospective study in Martinique. Clin Toxicol. 2016;54(4):313-8.

56. Morris JA, Akins JL. Feeding ecology of invasive lionfish (Pterois volitans) in the Bahamian archipelago. Environ Biol Fishes. 2009;86(3):389-98.

57. Albins M, Lyons P. Invasive red lionfish Pterois volitans blow directed jets of water at prey fish. Mar Ecol Prog Ser. 2012;448:1-5.

58. Maljković A, Van Leeuwen TE, Cove SN. Predation on the invasive red lionfish, Pterois volitans (Pisces: Scorpaenidae), by native groupers in the Bahamas. Coral Reefs. 2008;27(3):501.

59. Diller JL, Frazer TK, Jacoby CA. Coping with the lionfish invasion: evidence that naïve, native predators can learn to help. J Exp Mar Bio Ecol. 2014;455:45-9.

60. Morris JA Jr, Whitfield PE. Biology, Ecology, Control and Management of the Invasive Indo-Pacific Lionfish: an Updated Integrated Assessment. NOAA Technical Memorandum NOS NCCOS 99. Beaufort, NC: NOAA; 2009.

61. Fishelson L. Experiments and observations on food consumption, growth and starvation in Dendrochirus brachypterus and Pterois volitans (Pteroinae, Scorpaenidae). Environ Biol Fishes. 1997;50(4):391-403.

62. Jud ZR, Layman CA, Lee JA, Arrington DA. Recent invasion of a Florida (USA) estuarine system by lionfish Pterois volitans/p. miles. Aquat Biol. 2011;13(1):21-6.

63. Claydon JAB, Calosso MC, Traiger SB. Progression of invasive lionfish in seagrass, mangrove and reef habitats. Mar Ecol Prog Ser. 2012;448:119-29.

64. Muñoz RC, Currin CA, Whitfield PE. Diet of invasive lionfish on hard bottom reefs of the Southeast USA: Insights from stomach contents and stable isotopes. Mar Ecol Prog Ser. 2011;432:181-93.

65. Albins M, Hixon M. Worst case scenario: potential longterm effects of invasive predatory lionfish (Pterois volitans) on Atlantic and Caribbean coral-reef communities. Environ Biol Fishes. 2013;96(10/11):1151-7.

66. Green SJ, Akins JL, Maljkovic A, Côté IM. Invasive lionfish drive Atlantic coral reef fish declines. PLoS One. 2012;7(3):e32596.

67. Albins M, Hixon M. Invasive Indo-Pacific lionfish Pterois volitans reduce recruitment of Atlantic coral-reef fishes. Mar Ecol Prog Ser. 2008;367:233-8.

68. Grieve BD, Curchitser EN, Rykaczewski RR. Range expansion of the invasive lionfish in the Northwest Atlantic with climate change. Mar Ecol Prog Ser. 2016;546:225-37.

69. Kletou D, Hall-Spencer JM, Kleitou P. A lionfish (Pterois miles) invasion has begun in the Mediterranean Sea. Mar Biodivers Rec. 2016;9(46).

70. Clark AT, Clark RF, Cantrell FL. A retrospective review of the presentation and treatment of stingray stings reported to a poison control system. Am J Ther. 2017; 24(2):e177-80.

71. Barnett S, Saggiomo S, Smout M, Seymour J. Heat deactivation of the stonefish Synanceia horrida venom - implications 
for first-aid management. Diving Hyperb Med. 2017;47(3): 155-8.

72. Kayal M, Vercelloni J, Lison de Loma T, Bosserelle P, Chancerelle Y, Geoffroy S, et al. Predator crown-ofthorns starfish (Acanthaster planci) outbreak, mass mortality of corals, and cascading effects on reef fish and benthic communities. PLoS One. 2012;7(10):e47363.

73. Uthicke S, Logan M, Liddy M, Francis D, Hardy N, Lamare M. Climate change as an unexpected co-factor promoting coral eating seastar (Acanthaster planci) outbreaks. Sci Rep. 2015;5(1):8402.

74. Hock K, Wolff NH, Ortiz JC, Condie SA, Anthony KRN, Blackwell PG, et al. Connectivity and systemic resilience of the Great Barrier Reef. PLOS Biol. 2017;15 (11):e2003355.

75. Pratchett MS, Schenk TJ, Baine M, Syms C, Baird AH. Selective coral mortality associated with outbreaks of Acanthaster planci L. in Bootless Bay, Papua New Guinea. Mar Environ Res. 2009;67(4-5):230-6.

76. Baird AH, Pratchett MS, Hoey AS, Herdiana Y, Campbell SJ. Acanthaster planci is a major cause of coral mortality in Indonesia. Coral Reefs. 2013;32 (3):803-12.

77. Kamya PZ, Byrne M, Mos B, Hall L, Dworjanyn SA. Indirect effects of ocean acidification drive feeding and growth of juvenile crown-of-thorns starfish, Acanthaster planci. Proc R Soc B Biol Sci. 2017;284(1856): 20170778.

78. Sato H, Tsuruta Y, Yamamoto YI, Asato Y, Taira K, Hagiwara K, et al. Case of skin injuries due to stings by crown-of-thorns starfish (Acanthaster planci). J Dermatol. 2008;35(3):162-7.

79. Shiomi KA, Kazama A, Shimakura K, Nagashima Y. Purification and properties of phospholipases A2 from the crown-of- thorns starfish (Acanthaster planci) venom. Toxicon. 1998;36(4):589-99.

80. Shiomi K, Midorikawa S, Ishida M, Nagashima Y, Nagai H. Plancitoxins, lethal factors from the crown-of-thorns starfish Acanthaster planci, are deoxyribonucleases II. Toxicon. 2004;44(5):499-506.

81. Karasudani I, Koyama T, Nakandakari S, Aniya Y. Purification of anticoagulant factor from the spine venom of the crown-of-thorns starfish, Acanthaster planci. Toxicon. 1996;34(8):871-9.

82. Lin B, Norris RL, Auerbach PS. A case of elevated liver function tests after crown-of-thorns (Acanthaster planci) envenomation. Wilderness Environ Med. 2008;19(4): 275-9.

83. Ihama Y, Fukasawa M, Ninomiya K, Kawakami Y, Nagai T, Fuke C, et al. Anaphylactic shock caused by sting of crown-of-thorns starfish (Acanthaster planci). Forensic Sci Int. 2014;236:e5-8.

84. Smith HM, Smith RB, Sawin HL. A summary of snake classification (Reptilia, Serpentes). J Herpetol. 1977;11 (2):115-21.

85. Heatwole H. Sea Snakes. Malabar, FL: Krieger Publishing Company; 1999.
86. Gordon L. Blame El Niño for poisonous sea snake found on Ventura County beach. LA Times. October 16. 2015 .

87. Tandavanitj N, Mitani S, Toda M. Origins of Laticauda laticaudata and Laticauda semifasciata (Elapidae: Laticaudinae) individuals collected from the main islands of Japan as inferred from molecular data. Curr Herpetol. 2013;32(2):135-41.

88. Kharin VE. Redescription of a Russian finding of the erabu sea krait Pseudolaticauda semifasciata (Reinwardt in Schlegel, 1837), with remarks about species composition of sea snakes (Serpentes: Laticaudidae, Hydrophiidae) in Russian and adjacent waters. Russ J Mar Biol. 2009;35(1):8-14.

89. Park J, Kim I-H, Koo K-S, Park D. First record of Laticauda semifasciata from Korea. Anim Syst Evol Diversity. 2016;32(2):148-52.

90. Tamiya N, Arai H. Studies on sea-snake venoms. Crystallization of erabutoxins a and b from Laticauda semifasciata venom. Biochem J. 1966;99(3):624-30.

91. Park J, Kim IH, Fong JJ, Koo K-S, Choi W-J, Tsai T-S, et al. Northward dispersal of sea kraits (Laticauda semifasciata) beyond their typical range. PLoS One. 2017;12(6):e0179871.

92. Lillywhite HB, Babonis LS, Sheehy CM, Tu M-C. Sea Snakes (Laticauda spp.) require fresh drinking water: implication for the distribution and persistence of populations. Physiol Biochem Zool. 2008;81(6): 785-96.

93. Brischoux F, Tingley R, Shine R, Lillywhite HB. Salinity influences the distribution of marine snakes: implications for evolutionary transitions to marine life. Ecography (Cop). 2012;35(11):994-1003.

94. Lillywhite $\mathrm{HB}, \mathrm{Tu} \mathrm{MC}$. Abundance of sea kraits correlates with precipitation. PLoS One. 2011;6(12): e28556.

95. Hulme M, Osborn TJ, Johns TC. Precipitation sensitivity to global warming: comparison of observations with HadCM2 simulations. Geophys Res Lett. 1998;25(17): 3379-82.

96. Rasmussen AR, Murphy JC, Ompi M, Gibbons JW, Uetz P. Marine reptiles. In: Clifton J, ed. PLoS One; 2011: e27373.

97. Goiran C, Shine R. Decline in sea snake abundance on a protected coral reef system in the New Caledonian Lagoon. Coral Reefs. 2013;32(1):281-4.

98. Lukoschek V, Beger M, Ceccarelli D, Richards Z, Pratchett M. Enigmatic declines of Australia's sea snakes from a biodiversity hotspot. Biol Conserv. 2013;166: $191-202$.

99. Lawler JJ, Shafer SL, Blaustein AR. Projected climate impacts for the amphibians of the western hemisphere. Conserv Biol. 2010;24(1):38-50.

100. Corn PS. Climate change and amphibians. Anim Biodivers Conserv. 2005;1(1):59-67.

101. Alford RA, Bradfield KS, Richards SJ. Global warming and amphibian losses. Nature. 2007;447(7144):E3-4. 
102. Pounds JA, Fogden MPL, Campbell JH. Biological response to climate change on a tropical mountain. Nature. 1999;398(6728):611-5.

103. Pounds JA. Climate and amphibian declines. Nature. 2001;410(6829):639-40.

104. Pounds JA, Bustamante MR, Coloma LA, Consuegra JA, Fogden MP, Foster PN, et al. Widespread amphibian extinctions from epidemic disease driven by global warming. Nature. 2006;439(12):161-7.

105. Donnelly MA, Crump ML. Potential effects of climate change on two neotropical amphibian assemblages. Clim Change. 1998;39(2-3):541-61.

106. Carey C, Alexander MA. Climate change and amphibian declines:is there a link? Divers Distrib. 2003;9(2): 111-21.

107. Lips KR, Diffendorfer J, Mendelson JR, Sears MW. Riding the wave: reconciling the roles of disease and climate change in amphibian declines. PLoS Biol. 2008;6(3):e72.
108. Garner TWJ, Rowcliffe JM, Fisher MC. Climate change, chytridiomycosis or condition: an experimental test of amphibian survival. Glob Chang Biol. 2011;17(2):667-75.

109. Pessier AP, Nichols DK, Longcore JE, Fuller MS. Cutaneous chytridiomycosis in poison dart frogs (Dendrobates spp.) and White's tree frogs (Litoria caerulea). J Vet Diagnostic Investig. 1999;11(2):194-9.

110. Seimon TA, Seimon A, Daszak P, Halloy SRP, Schloegel LM, Aguilar CA, et al. Upward range extension of Andean anurans and chytridiomycosis to extreme elevations in response to tropical deglaciation. Glob Chang Biol. 2007;13(1):288-99.

111. Hornbeak KB, Auerbach PS. Marine envenomation. Emerg Med Clin North Am. 2017;35(2):321-37.

112. Wake DB, Vredenburg VT. Are we in the midst of the sixth mass extinction? A view from the world of amphibians. Proc Natl Acad Sci. 2008;105(Suppl 1): 11466-73. 